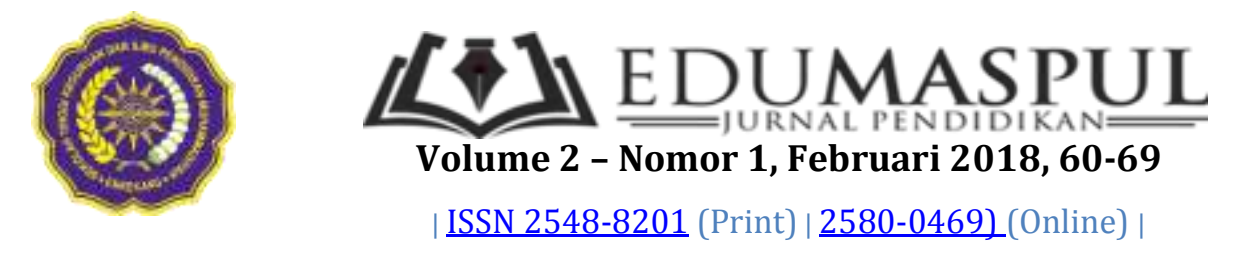

\title{
RANCANG BANGUN APLIKASI KAMUS BAHASA MASSENREMPULU BERBASIS WEB
}

\author{
AGUSRIANDI AGUSRIANDI \\ STKIP Muhammadiyah Enrekang/ Enrekang \\ E-mail:agusriandi595@gmail.com
}

\begin{abstract}
Abstrak
Penelitian ini didasarkan pada keprihatinan terhadap salah satu budaya/bahasa lokal di Sulawesi Selatan yang secara perlahan namun pasti tergerus oleh perkembangan zaman. Tujuan penelitian ini adalah untuk menerapkan pencarian secara dinamis berbasis web untuk menampilkan padanan kata, gambar, dan contoh kalimat bahasa Massenrempulu Kabupaten Enrekang, Sulawesi Selatan sesuai dengan kata yang dimasukkan dalam bahasa Indonesia. Tahapan penelitian ini adalah: (1) Menentukan fungsi utama; (2) Perancangan aplikasi; (3) Implementasi pencarian secara dinamis menggunakan live search AJAX pada aplikasi kamus Massenrempulu. Berdasarkan penelitian ini telah dihasilkan sebuah aplikasi kamus Bahasa Massenrempulu berbasis web dengan model pencarian yang sangat dinamis berbasis web.
\end{abstract}

Kata Kunci: Aplikasi, AJAX, Kamus, Massenrempulu, Web

\section{PENDAHULUAN}

Bahasa Massenrempulu sebagai bahasa lokal yang digunakan masyarakat di Kabupaten Enrekang, Sulawesi Selatan. Perlahan tapi pasti bahasa lokal ini mulai tergerus oleh perkembangan zaman. Masuknya budaya-budaya luar, terjadinya perkawinan silang, serta banyaknya orang tua mereka yang merantau sehingga mereka tidak mengenal lagi bahasa "Ibu" mereka. Disamping itu, bahasa merupakan budaya lokal tidak ternilai harganya yang harus dipertahankan demi identitas sebuah etnik.

\begin{tabular}{lrr}
\multicolumn{1}{r}{ Seiring dengan perkembangan } \\
zaman, maka berkembang pula \\
penggunaan internet. Internet merupakan \\
international & network r yang \\
memungkinkan setiap orang dapat
\end{tabular}

mencari dan menemukan informasi yang ada seluruh dunia. Tidak terkecuali informasi seperti kamus bahasa massenrempulu yang berbasis web. Namun, sebuah aplikasi yang berbasis web haruslah menarik dan fleksibilitas dalam penggunaannya. Oleh karena itu, penelitian ini menggunakan live search $A J A X$ sebagai salah satu fitur untuk memudahkan pencarian dinamis yang tidak sebatas arti kata saja tapi disertai dengan gambar dan kalimat.

Kabupaten Enrekang adalah salah satu Daerah Tingkat II di provinsi Sulawesi Selatan, Indonesia. Ibu kota kabupaten ini terletak di Kota Enrekang. Kabupaten ini memiliki luas wilayah $1.786,01 \mathrm{~km}^{2}$ dan berpenduduk sebanyak \pm 190.579 jiwa. 
Ditinjau dari segi sosial budaya, masyarakat Kabupaten Enrekang memiliki kekhasan tersendiri. Hal tersebut disebabkan karena kebudayaan Enrekang (Massenrempulu') berada di antara kebudayaan Bugis, Mandar dan Tana Toraja. Bahasa daerah yang digunakan di Kabupaten Enrekang secara garis besar terbagi atas 3 bahasa dari 3 rumpun etnik yang berbeda di Massenrempulu.[1].

Sedangkan menurut Sitti Hawang Hanafie, (1983) dialek bahasa Massenrempulu ada 4 jenis. 4 jenis tersebut adalah yaitu dialek Dun, dialek Endekan, dialek Maiwa, dan dialek Patinjo.[2] Namun, karena daerah Patinjo masuk ke wilayah Pinrang maka yang masuk daerah Enrekang hanya 3 dialek. Dialek Maiwa sebagian besar dituturkan warga yang berdomisili di wilayah perbatasan Sidrap. Dialek Enrekang tuturkan warga di Kecamatan Cendana dan Kecamatan Enrekang atau di pusat pemerintahan Kabupaten Enrekang. Sementara kelompok masyarakat Duri meliputi warga yang bermukim di wilayah Kecamatan Baraka, Anggeraja, Malua, Curio, dan Alla. Ketiga kelompok masyarakat ini masing-masing memiliki bahasa dengan beberapa kosa kata, dialek, dan aksen yang berbeda.warga asli Enrekang bahkan mengakui, kadangkadang masih sulit memahami arti bahasa warganya yang dari Maiwa [3].

Dalam pembuatan aplikasi ini, ada beberapa tools dan bahasa pemrograman yang digunakan. Tools dan bahasa pemrograman yang dimaksud adalah sebagai berikut:

\subsection{MYSQL}

MySQL adalah sebuah perangkat lunak sistem manajemen basis data SQL (bahasa Inggris: database management system) atau DBMS yang multithread, multi-user, dengan sekitar 6 juta instalasi di seluruh dunia. MySQL AB membuat MySQL tersedia sebagai perangkat lunak gratis dibawah lisensi GNU General Public License (GPL), tetapi mereka juga menjual dibawah lisensi komersial untuk kasus-kasus dimana penggunaannya tidak cocok dengan penggunaan GPL.[3].

MySQL mudah untuk digunakan (easy-to-use) dan sebagai sistem manajemen database relasional (RDBMS) yang digunakan untuk database pada beberapa website. Kecepatan adalah fokus utama pada pengembangan awal MySQL. Demi kepentingan kecepatan ini, mereka membuat keputusan untuk menawarkan fitur lebih sedikit dibanding pesaing utama mereka (seperti oracle dan Sybase). MySQL adalah lebih mudah dalam instalasi dan penggunaannya dibanding pesaing komersialnya. Di dalam harga, MySQL benar-benar murah. [4]

\subsection{PHP}

PHP atau Hypertext Preprocessor adalah bahasa skrip yang dapat ditanamkan atau disisipkan ke dalam HTML. PHP banyak dipakai untuk memrogram situs web dinamis. PHP dapat digunakan untuk membangun sebuah CMS. Pada awalnya PHP merupakan kependekan dari Personal Home Page (Situs personal). PHP pertama kali dibuat oleh Rasmus Lerdorf pada tahun 1995. Pada waktu itu PHP masih bernama Form Interpreted (FI), yang wujudnya berupa sekumpulan skrip yang digunakan untuk mengolah data formulir dari web.

Selanjutnya Rasmus merilis kode sumber tersebut untuk umum 
dan menamakannya PHP/FI. Dengan perilisan kode sumber ini menjadi sumber terbuka, maka banyak pemrogram yang tertarik untuk ikut mengembangkan PHP. Pada November 1997, dirilis PHP/FI 2.0. Pada rilis ini, interpreter PHP sudah diimplementasikan dalam program C. Dalam rilis ini disertakan juga modul-modul ekstensi yang meningkatkan kemampuan PHP/FI secara signifikan.

Pada tahun 1997, sebuah perusahaan bernama Zend menulis ulang interpreter PHP menjadi lebih bersih, lebih baik, dan lebih cepat. Kemudian pada Juni 1998, perusahaan tersebut merilis interpreter baru untuk PHP dan meresmikan rilis tersebut sebagai PHP 3.0 dan singkatan PHP diubah menjadi akronim berulang PHP: Hypertext Preprocessing.

Pada pertengahan tahun 1999, Zend merilis interpreter PHP baru dan rilis tersebut dikenal dengan PHP 4.0. PHP 4.0 adalah versi PHP yang paling banyak dipakai pada awal abad ke-21. Versi ini banyak dipakai disebabkan kemampuannya untuk membangun aplikasi web kompleks tetapi tetap memiliki kecepatan dan stabilitas yang tinggi.

Pada Juni 2004, Zend merilis PHP 5.0. Dalam versi ini, inti dari interpreter PHP mengalami perubahan besar. Versi ini juga memasukkan model pemrograman berorientasi objek ke dalam PHP untuk menjawab perkembangan bahasa pemrograman ke arah paradigma berorientasi objek.[5].

\subsection{AJAX}

Asynchronous JavaScript
and XMLHTTP, atau disingkat
AJaX, adalah suatu teknik
pemrograman berbasis web untuk
menciptakan aplikasi web interaktif.
Tujuannya adalah r untuk
memindahkan sebagian besar interaksi pada komputer web surfer, melakukan pertukaran data dengan server di belakang layar, sehingga halaman web tidak harus dibaca ulang secara keseluruhan setiap kali seorang pengguna melakukan perubahan. Hal ini akan meningkatkan interaktivitas, kecepatan, dan usability. Ajax merupakan kombinasi dari: DOM yang diakses dengan client side scripting language, seperti VBScript dan implementasi ECMAScript seperti JavaScript dan JScript, untuk menampilkan secara dinamis dan berinteraksi dengan informasi yang ditampilkan Objek XMLHTTP dari Microsoft atau XMLHttpRequest yang lebih umum diimplementasikan pada beberapa browser. Objek ini berguna sebagai kendaraan pertukaran data asinkronus dengan web server. Pada beberapa framework AJAX, element HTML IFrame lebih dipilih daripada XMLHTTP atau XMLHttpRequest untuk melakukan pertukaran data dengan web server.

XML umumnya digunakan sebagai dokumen transfer, walaupun format lain juga memungkinkan, seperti HTML, plain text. XML dianjurkan dalam pemakaian teknik AJaX karena kemudahan akses penanganannya dengan memakai DOM JSON dapat menjadi pilihan alternatif sebagai dokumen transfer, mengingat JSON adalah JavaScript 
itu sendiri sehingga penanganannya lebih mudah.

Seperti halnya DHTML, LAMP, atau SPA, Ajax bukanlah teknologi spesifik, melainkan merupakan gabungan dari teknologi yang dipakai bersamaan. Bahkan, teknologi turunan/komposit yang berdasarkan Ajax, seperti AFLAX sudah mulai bermunculan.[6].

\section{METODE PENELITIAN}

Tahapan penelitian ini disusun dalam urutan-urutan langkah kerja dalam bentuk diagram alir ditunjukkan pada gambar di bawah ini:

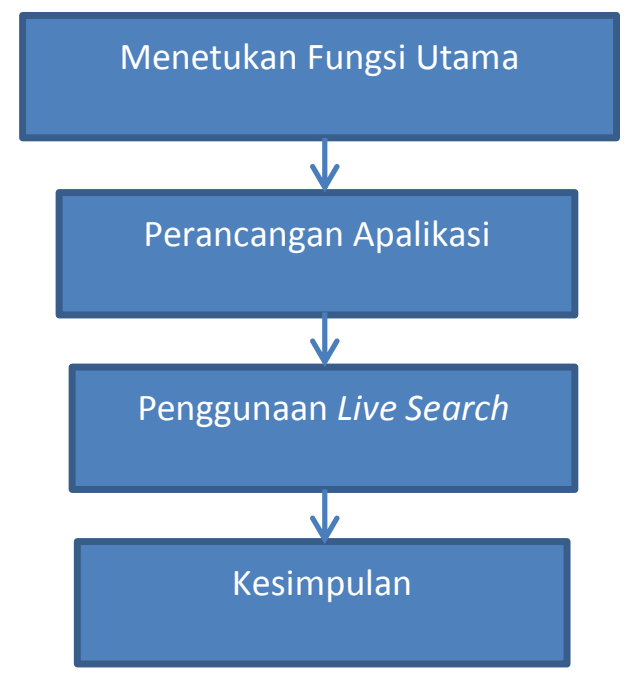

Gambar 3.1 Tahapan Penelitian

Tahapan penelitian yang dilakukan, dijelaskan sebagai berikut:

a. Menentukan fungsi utama. Fungsi utama pada penelitian ini adalah bagaimana menerapkan live search pada Aplikasi Kamus Massenrempulu Berbasis Online;

b. Perancangan Aplikasi. Pada tahap ini, akan dilakukan perancangan apalikasi yang terdiri dari antarmuka administrator, antarmuka pengunjung dan rancangan basis data;

c. Penggunaan Live Search. Setelah melakukan peracangan aplikasi, akan dilakukan coding sehingga penggunaan live search dapat terealisasi;

d. Kesimpulan. Kesimpulan dan hasil penelitian.

\section{PEMBAHASAN}

\subsection{Analisis Fungsi Utama}

Masalah fungsi yang menjadi fokus penelitian ini adalah bagaimana melakukan pencarian padanan kata tanpa perlu menekan tombol search pada kamus Massenrempulu berbasis online. Para pengguna cukup mengetikkan kata kunci yang diinginkan, maka akan tampil padanan kata dan gambar serta contoh kalimat.

\subsection{Perancangan Aplikasi}

Aplikasi Kamus

Massenrempulu Berbasis Online terdiri dari tiga bagian utama, antarmuka pengguna, modul administrator dan basis data. Oleh sebab itu, dirancang file HTML untuk antarmuka pengguna dan file PHP untuk menerapkan modul administrator. Semua file akan disimpan pada hosting berbayar.

\section{a. Rancangan Antarmuka Pengguna}

Rancangan antarmuka pengguna digunakan untuk mensimulasikan entri kata bahasa Indonesia yang dicari artinya dalam bahasa Massenrempulu yang disertai dengan contoh kalimat dan gambar.Antarmuka ini dirancang untuk para pemakai PC. Informasi yang dirancang dari antarmuka ini dapat digambarkan sebagai berikut: 


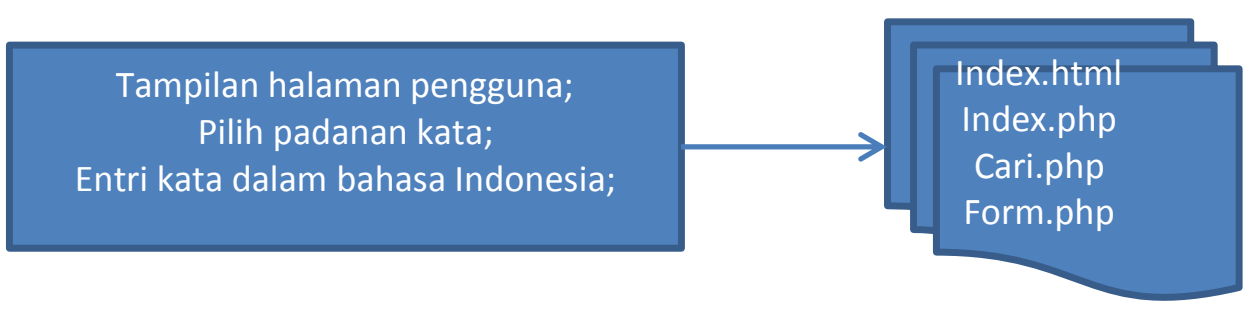

Gambar 3.1 Susunan File Pada Antarmuka Pengguna

Guna memudahkan pemahaman hubungan antar file tersebut, gambar 3.2 menyajikan bagan arus data yang menandai adanya hubungan dari file ini, pada bagianbagian yang berbeda pada antarmuka pengguna.

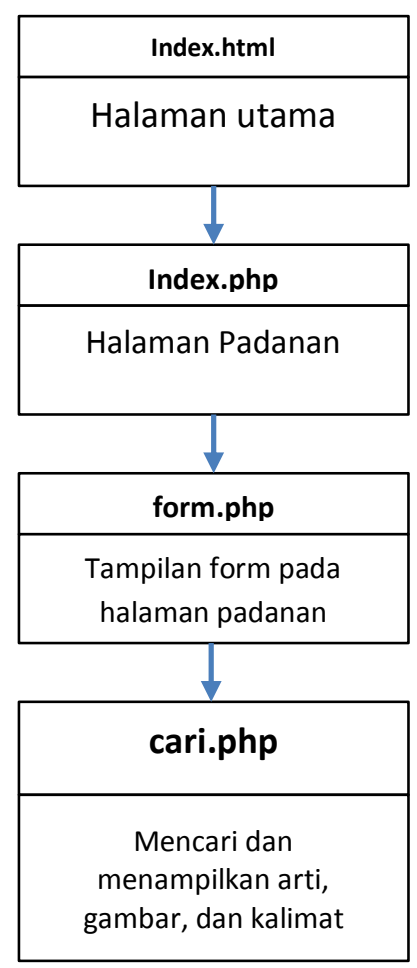

Gambar 3.2 Hubungan File-file pada Antarmuka Pengguna

\section{b. Rancangan Modul Administrator}

Modul administrator digunakan untuk mengendalikan server web. Ini direncanakan untuk membuat, menambah, menghapus dan mengedit item-item kata, arti, gambar, dan kalimat. Informasi yang dirancang dari modul ini dapat digambarkan sebagai berikut:

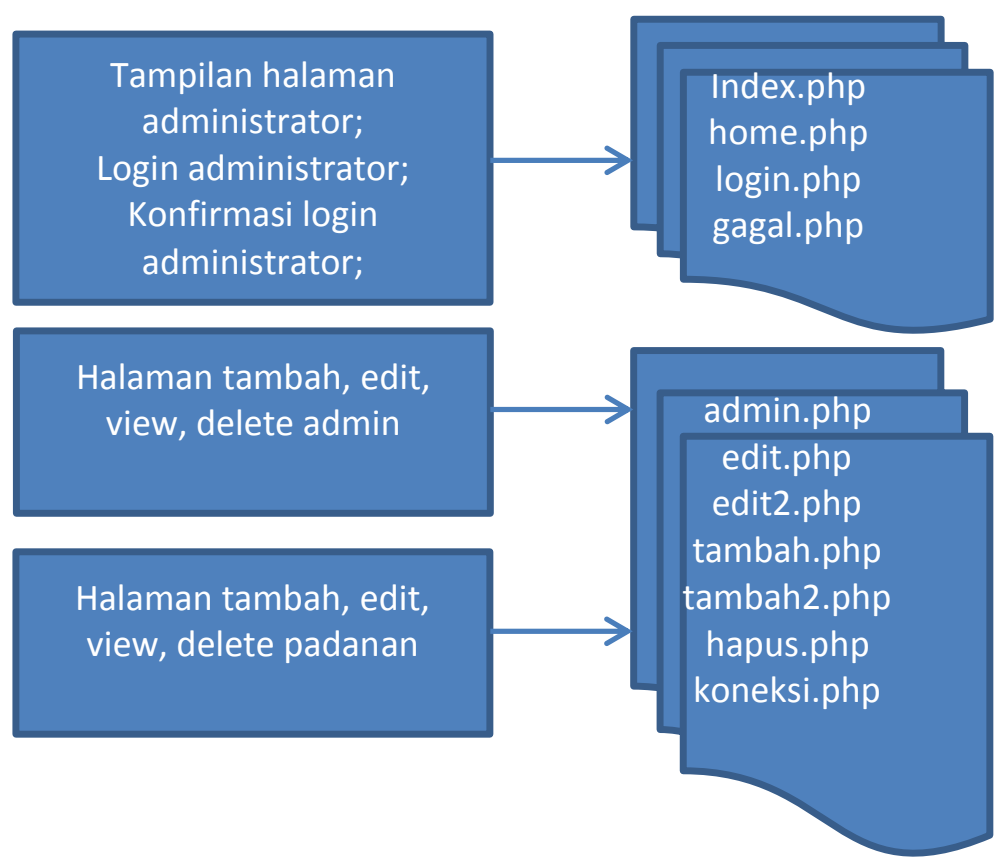

Gambar 3.3 Susunan file pada Modul Administrator 
Guna memudahkan pemahaman hubungan antar file tersebut, gambar 3.4 menyajikan bagan arus data yang menandai adanya hubungan dari file ini, pada bagianbagian yang berbeda pada antarmuka pengguna.

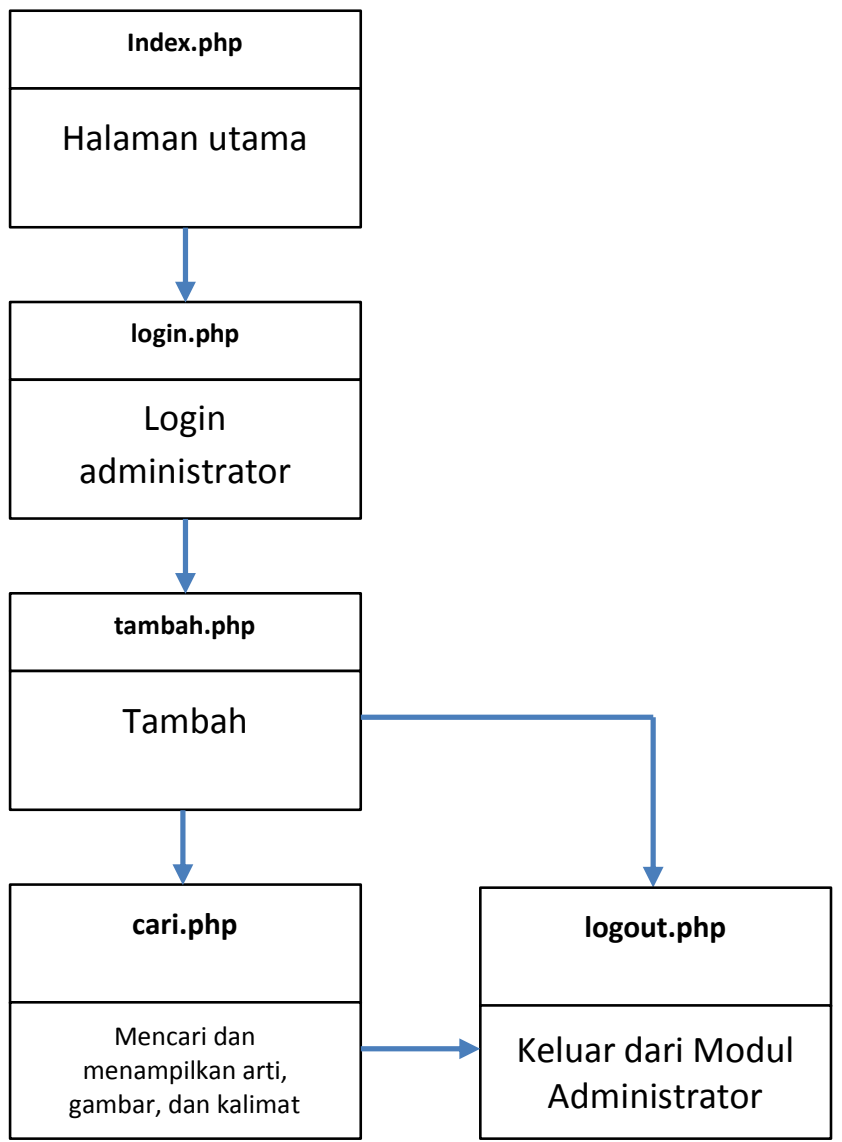

Gambar 3.4 Susunan file pada Modul Administrator

\section{c. Rancangan Basis Data}

Setiap aplikasi setidaknya memiliki basis data sebagai tempat menampung data-data yang dimasukkan melalui form. Supaya basis data dapat dibuat, maka diperlukan DBMS atau Database Manajemen System. DBMS yang digunakan pada penelitian ini adalah
MySQL. SQL untuk membuat basis data dapat dilihat di bawah ini:

Create database kamus;

Setelah basis data dibuat, langkah selanjutnya adalah membuat tabel yang terdiri dari field-field id, kata, gambar, arti, dan kalimat. Query di bawah ini memperlihatkan tabel yang dibuat.

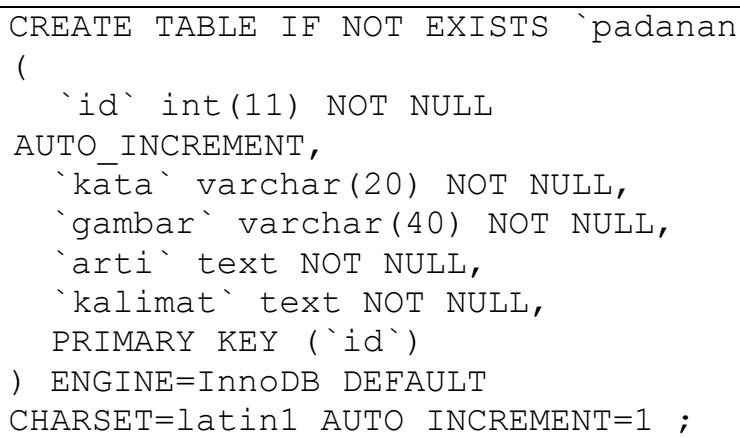

Pada query di atas, terdapat field id sebagai primary key yang dimaksudkan sebagai field index utama pengurutan data.

\section{d. Penggunaan Live Search AJAX}

Penggunaan Live Search AJAX dimulai dengan membuat kode untuk mendapatkan halaman view masing masing tabel. Kode program pada lihat seperti di bawah ini:

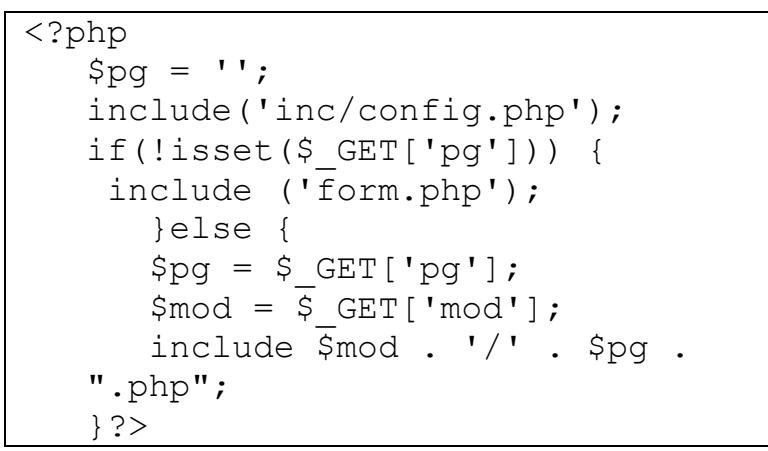


Kode program di atas, disimpan dengan nama index.php

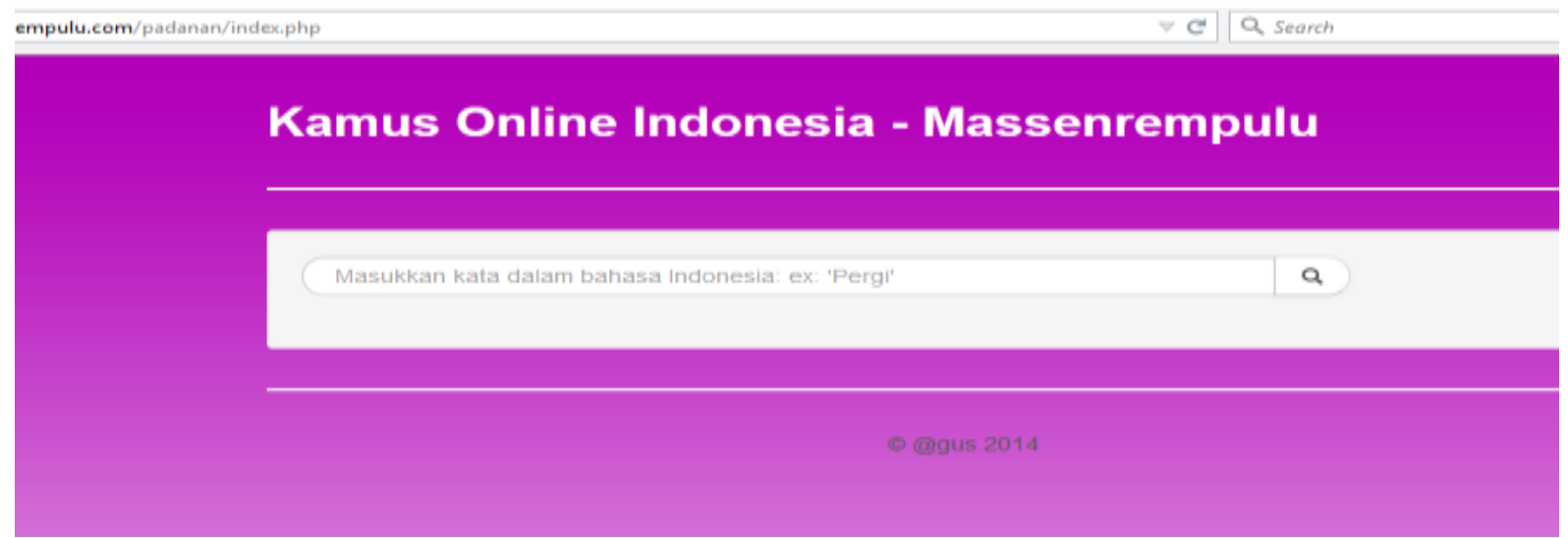

Gambar 3.5 Tampilan Halaman Utama

Tahap selanjutnya, membuat kode pada tabel padanan berdasarkan kata program untuk melakukan select data kunci yang dimasukkan. Berikut kode program yang dimaksud:

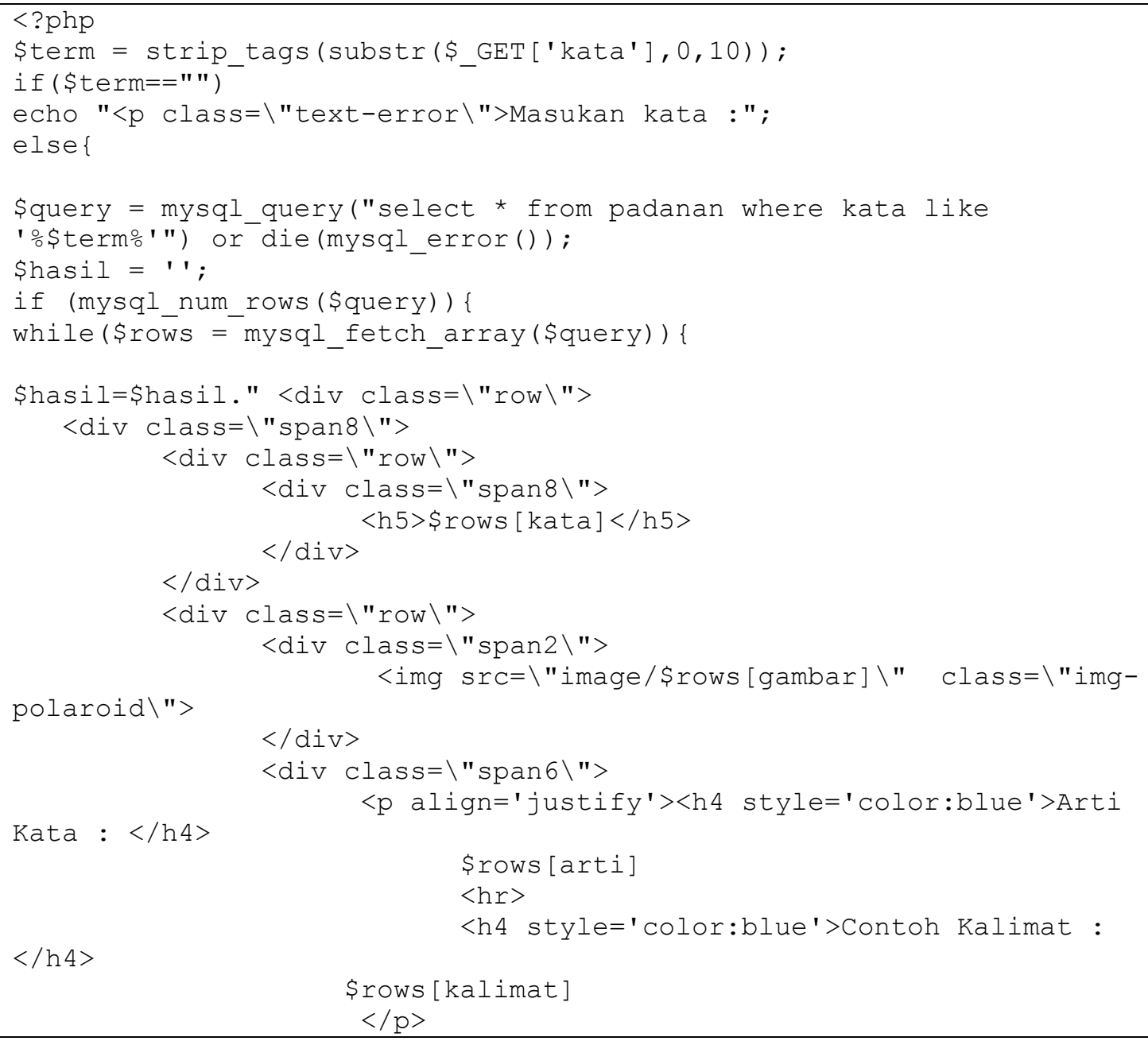




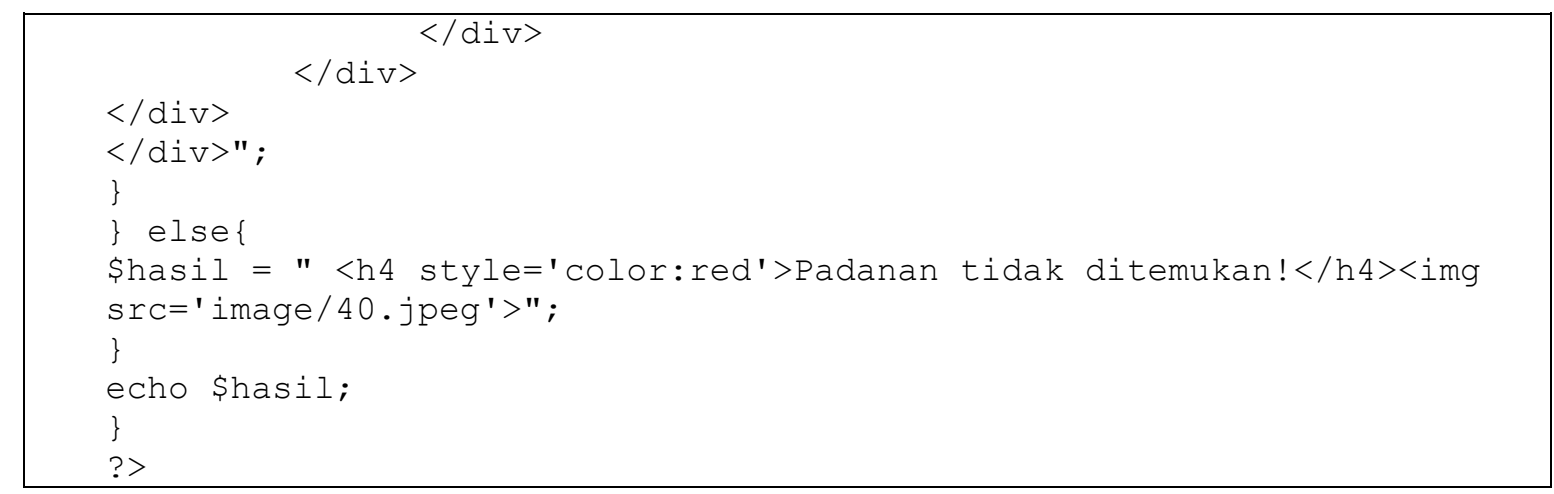

Kode program di atas, disimpan dengan nama cari.php. Untuk menampilkan arti kata, gambar dan contoh kalimat yang diinginkan, cukup dengan mengetik kata kunci pada text field pencarian.

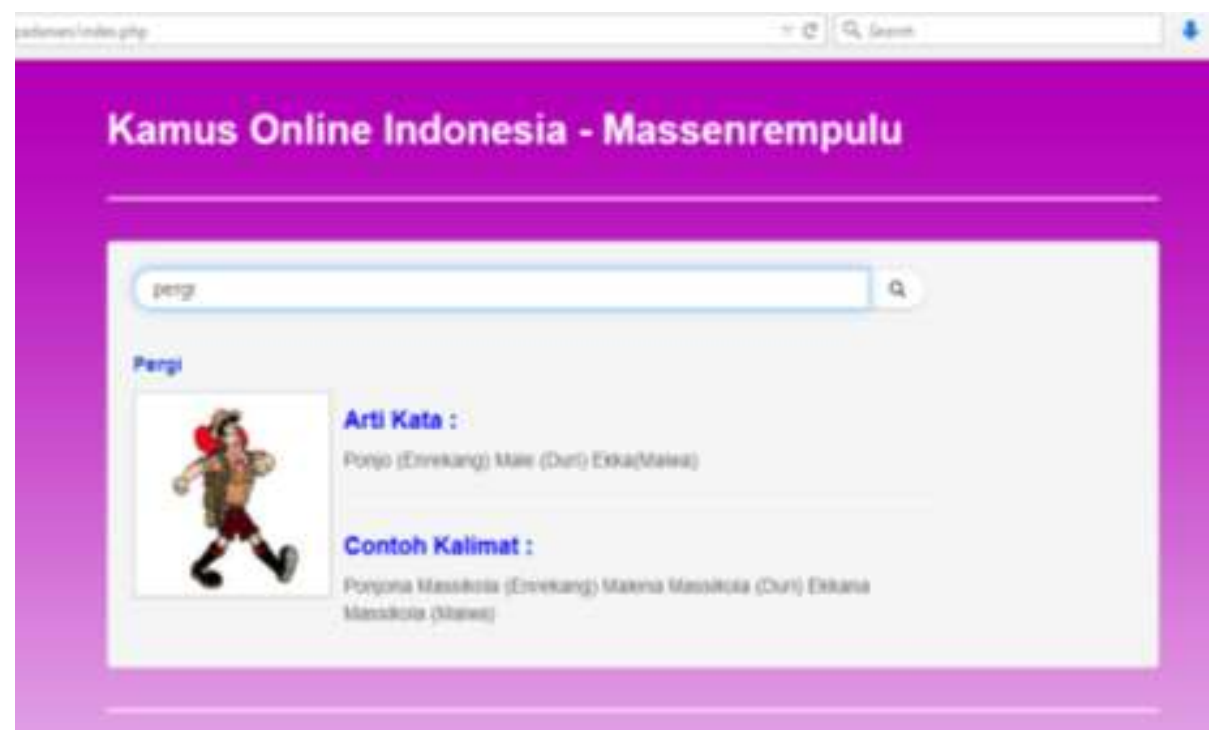

Gambar 3.6 Hasil Pencarian

Penggunaan live search Ajax dapat dilihat pada kode program di bawah ini:

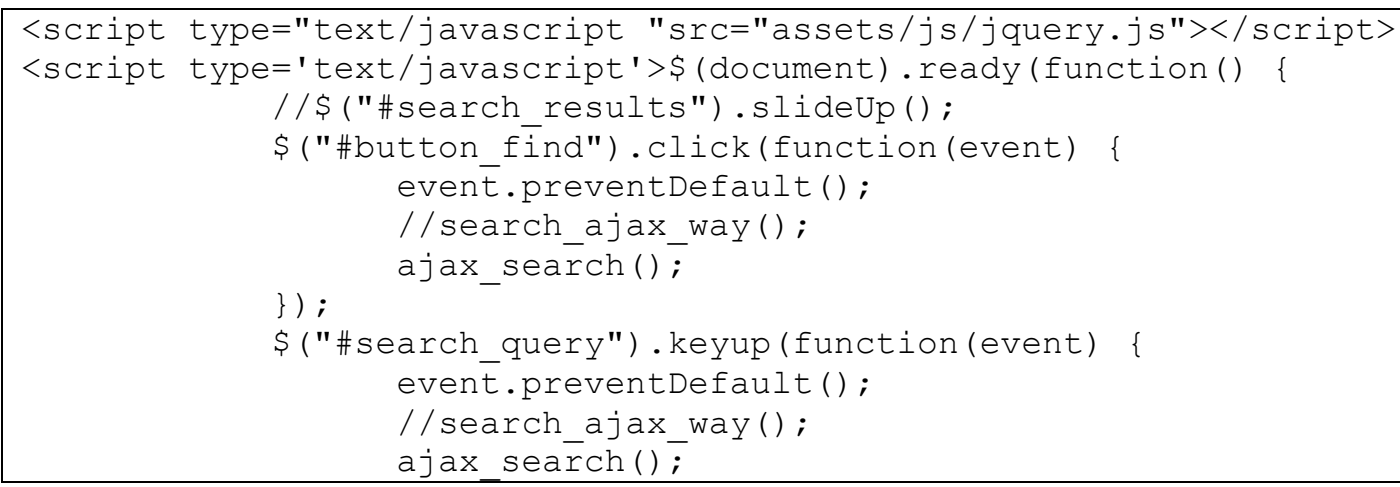




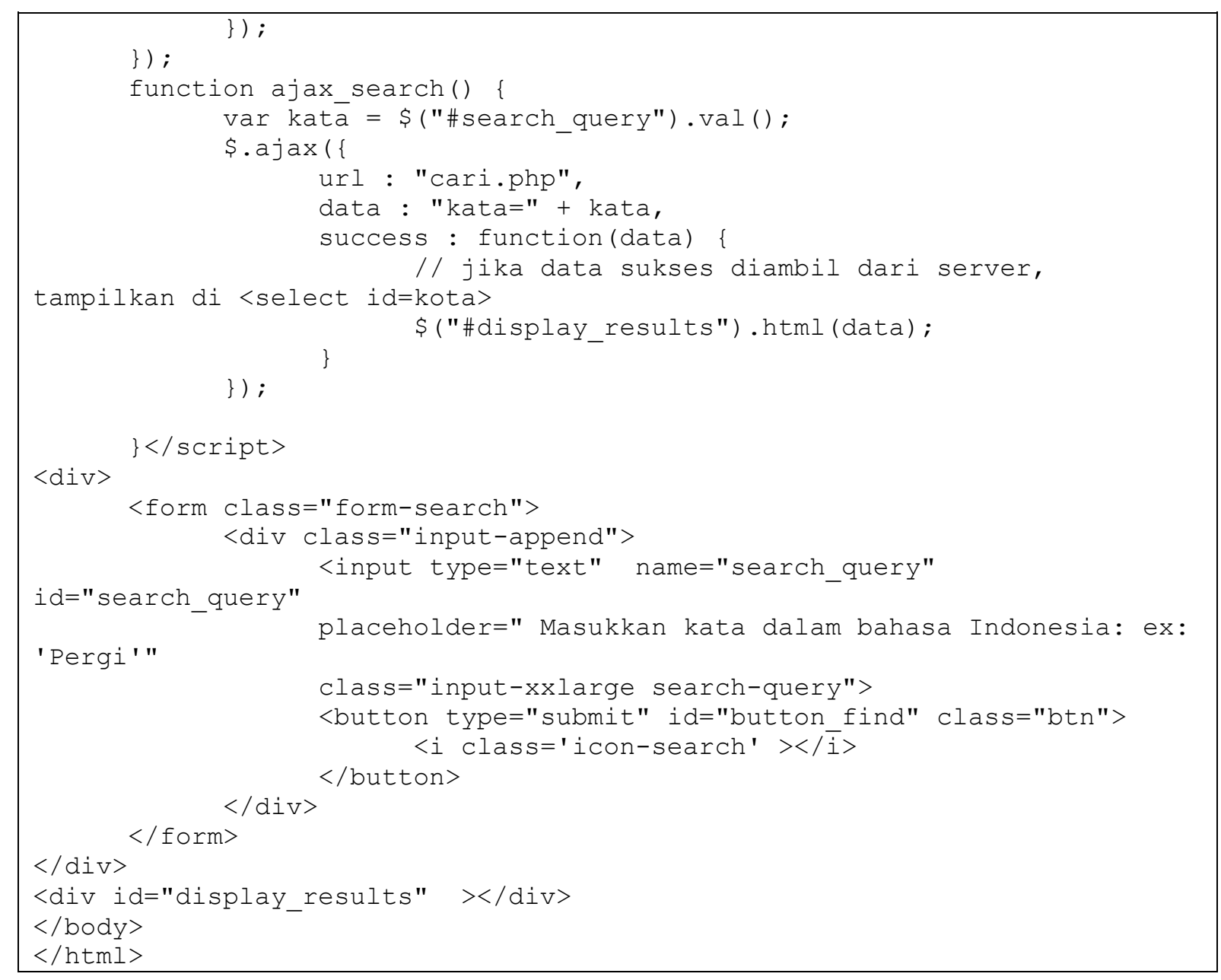

Pada kode program di atas, Aplikasi berbasis web dapat diakses melalui ditambahkan berbagai fungsi Ajax untuk internet dengan sehingga setiap orang dapat menampilkan data secara dinamis pada saat pengguna mengetikkan karakter atau pada saat pengguna menekan tombol enter.

\section{PENUTUP}

\subsection{Kesimpulan}

Berdasarkan hasil hasil penelitian ini, secara umum ditarik kesimpulan bahwa: 1 . Dihasilkan sebuah aplikasi kamus Massenrempulu dengan model pencarian padanan kata, gambar dan contoh kalimat mengaksesnya tanpa dibatasi ruang dan waktu.

\subsection{Saran}

Saran-saran yang dapat diambil dari hasil penelitian ini adalah sebagai berikut : 1 . Aplikasi ini masih membutuhkan kontribusi dari pemerhati bahasa Massenrempulu untuk menambahkan koleksi kata. 2. Penelitian ini masih butuh penelitian lanjutan untuk membuat versi mobile. 


\section{Daftar Pustaka}

[1] Wikipedia, 2015

http://id.wikipedia.org/wiki/Kabupaten

_Enrekang diakses 27 April 2015;

[2] Sitti Hawang Hanafie, K. L. (1983).

MORFOLOGI DAN SINTAKSIS

BAIIASA MASSEN EMPULU. Jakarta:

Departemen Pendidikan dan

Kebudayaan.

[3] Wikipedia, 2015

http://id.wikipedia.org/wiki/MySQL.

Diakses 30 April 2015
[4] Simartama, Janner., 2006. Aplikasi Mobile Commerce Menggunakan PHP dan MySQL. Yogyakarta: Andi.

[5] Wikipedia, 2015 http://id.wikipedia.org/wiki/PHP. Diakses 1 April 2015.

[6] Wikipedia, 2015 http://id.wikipedia.org/wiki/AJAX. Diakses 1 April 2015. 